\title{
Rapid detection of epidermal growth factor receptor mutations with multiplex PCR and primer extension in lung cancer
}

\author{
Ching-Hsiung Lin', Kun-Tu Yeh2, Ya-Sian Chang 3,4, Nicholas C Hsu³ and Jan-Gowth Chang*3,5,6
}

\begin{abstract}
Epidermal growth factor receptor (EGFR) kinase domain mutations hyperactivate the kinase and confer kinase addiction of the non-small-cell lung cancer (NSCLC) tumor cells. Almost all of these mutations are located within exons 18-21. The -216 single nucleotide polymorphism in the promoter region is associated with increased EGFR production. We present a method for detecting these common mutations in 81 cases of NSCLC. The protocol is based on the multiplex amplification of promoter region and exons 18-21 of the EGFR genes in a single tube, followed by primer extension of the PCR products using various sizes of primers to detect base changes at -216 promoter region and codons 719, 746$750,790,858$ of the EGFR gene. We compared the results with that from direct sequencing for detecting EGFR mutations in 81 cases of NSCLC. The two methods identified the same 26 mutations, but our method is superior to direct sequencing in terms of the amount of work and time required. We presented a simple and fast method to detect mutations of EGFR genes in NSCLC.
\end{abstract}

\section{Background}

Lung cancer is one of the most common cancers in the world and is responsible for one third of all cancer-related death. Treatment of lung cancer mainly depends on the type of the cells that make up the cancer. Small-cell lung cancer (SCLC) which comprises about $20 \%$ of lung cancers originates from neuroendocrine cells in the bronchus. SCLC responds well to chemotherapy initially, but resistance occurs commonly. Non-small-cell lung cancer (NSCLC), comprising $80 \%$ of lung cancers, arises from lung epithelial cells, and comprises diverse histological subtypes that includes adenocarcinoma, bronchioloalveolar, squamous, anaplastic and large-cell carcinomas [1]. NSCLC is often treated with combination cytotoxic chemotherapy, but the treatment only results in a modest increase in survival. The receptor tyrosine kinases (RTKs) serve as cell signalling mediators by receptor-specific ligands. Epidermal growth factor receptor (EGFR) is a member of the ErbB family of RTKs expressed in many cases of NSCLC, and its expression is correlated with a poor prognosis [2-5]. Two EGFR small molecule inhibi-

* Correspondence: jgchang@ms.kmuh.org.tw

${ }^{3}$ Department of Laboratory Medicine, Kaohsiung Medical University Hospital, Kaohsiung, Taiwan

Full list of author information is available at the end of the article tors, gefitinib and erlotinib, which target the tyrosine kinase domain of EGFR have been approved for the treatment of advanced NSCLC. Females, Asians, nonsmokers, and those with bronchioloalveolar carcinoma appear to derive the most benefit from gefitinib or erlotinib [6-10]. Molecular analysis showed that the majority of responders harbored specific mutations in the gene that encodes EGFR [8,10-12]. EGFR kinase domain mutations occur primarily in exons 18-21 which encode part of the tyrosine kinase (TK) domain [13-15]. Besides these EGFR kinase domain mutations, a common single nucleotide polymorphisms (SNP) located -216 bp upstream from the initiator ATG in the promoter region also has been identified. The SNP occurs at an important binding site for the transcription factor SP1 that is necessary for activation of EGFR promoter activity and correlates with increased promoter activity and expression of EGFR mRNA [16].

In this study, we performed multiplex amplification of exons 18-21 and promoter of EGFR using five pair of primers followed by primer extension to detect base changes or deletions in codons $719,746-750,790,858$, and -216 promoter to analyze the mutational frequency

() 2010 Lin et al; licensee BioMed Central Ltd. This is an Open Access article distributed under the terms of the Creative Commons AtBioMed Central tribution License (http://creativecommons.org/licenses/by/2.0), which permits unrestricted use, distribution, and reproduction in any medium, provided the original work is properly cited. 
in 81 cases of lung cancer, and compared the results to that obtained by direct sequencing.

\section{Methods}

\section{Tissue Procurement}

Tumor specimens, obtained from patients on protocols approved by the Institutional Review Board of Changhua Christian Hospital, were collected from eighty-one patients with NSCLC at the time of surgical resection before systemic treatment. All specimens were frozen immediately and stored in liquid nitrogen until DNA was extracted.

\section{DNA extraction, PCR and direct sequencing of the EGFR gene}

DNA extraction was performed as previously described [17]. Five separate PCR reactions, each with the corresponding pair of primers, were used to amplify the promoter region and exons 18-21 of the EGFR genes (Table 1). PCR amplification of $0.2 \mu \mathrm{g}$ DNA was performed with a denaturing step at $94^{\circ} \mathrm{C}$ for $5 \mathrm{~min}$, then $30 \mathrm{sec}$ at $94^{\circ} \mathrm{C}, 1$ $\min$ at $58^{\circ} \mathrm{C}$, and $1 \mathrm{~min}$ at $72^{\circ} \mathrm{C}$ for 35 cycles, followed by a final $5 \mathrm{~min}$ at $72^{\circ} \mathrm{C}$. The PCR products were visualized on a $2.5 \%$ agarose gel. These PCR products were then subjected to direct sequencing using the same primers, and all mutations were confirmed by sequences originating from both the upstream and downstream primers. Direct sequencing was performed on a Beckman Coulter CEQ 8000 Series Genetic Analysis System (Beckman Coulter Inc., Fullerton, CA, USA) according to manufacturer instructions.

Multiplex PCR and primer extension analysis of mutations in EGFR-216 promoter region and exons 18, 19, 20, and 21 Multiplex PCR was used to amplify the promoter region and exons 18-21 of the EGFR genes in a single tube. The primers and conditions used for the multiplex PCR were

Table 1: PCR Primers used to amplify promoter region and exons 18, 19, 20, and 21 of the EGFR genes

\begin{tabular}{ll}
\hline EGFR gene & Sequence \\
\hline E18-5' & 5'-CTGGCACTGCTTTCCAGCAT-3' \\
E18-3' & 5'-GCTTGCAAGGACTCTGGGCT-3' \\
E19-5' & 5'-GCATCGCTGGTAACATCCAC-3' \\
E19-3' & 5'-AGATGAGCAGGGTCTAGAGC-3' \\
E20-5' & 5'-ATCGCATTCATGCGTCTTCA-3' \\
E20-3' & 5'-AGACCGCATGTGAGGATCCT-3' \\
E21-5' & 5'-TGACCCTGAATTCGGATGCA-3' \\
E21-3' & 5'-ATACAGCTAGTGGGAAGGCA-3' \\
Promoter 5' & 5'-CCTCCTCTGCTCCTCCCGAT-3' \\
Promoter 3' & 5'-CGGGGCTAGCTCGGGACT-3' \\
\hline
\end{tabular}

the same as the PCR described above. After multiplex PCR amplification, the PCR products were purified to remove the remaining primers and unincorporated deoxynucleotide triphosphates, using the PCR- $\mathrm{M}^{\text {tw }}$ Clean Up System (Viogene-biotek Co., Sunnyvale, CA, USA). After removing the primers, the products were subjected to primer extension analysis. Various concentrations of probe for -216 promoter region and exons 18-21 were added to the tube containing $1.5 \mu \mathrm{l}$ of purified PCR products (Table 2), as well as $4 \mu \mathrm{l}$ of ABI PRISM SNaPshot Multiplex Kit (Applied Biosystems, Foster City, CA) containing AmpliTaq DNA polymerase and fluorescently labeled dideoxynucleotide triphosphates (ddNTPs) (RGG-labeled dideoxyadenosine triphosphate, TAMRAlabeled dideoxycytidine triphosphate, ROX-labeled dideoxythymidine triphosphate, and R110-labeled dideoxyguanosine triphosphate). Each $10-\mu \mathrm{l}$ mixture was subjected to 25 single-base extension cycles consisting of a denaturing step at $96^{\circ} \mathrm{C}$ for $10 \mathrm{sec}$, and primer annealing and extension at $60^{\circ} \mathrm{C}$ for $35 \mathrm{sec}$. After cycle extension, unincorporated fluorescent ddNTPs were incubated with $1 \mu \mathrm{l}$ of shrimp alkaline phosphatase (SAP) (United States Biochemical Co., Cleveland, USA), at $37^{\circ} \mathrm{C}$ for 1 hour, followed by enzyme deactivation at $75^{\circ} \mathrm{C}$ for $15 \mathrm{~min}$.

The primer extension reaction products were resolved by automated capillary electrophoresis on a capillary electrophoresis platform. Briefly, $14 \mu \mathrm{l}$ of $\mathrm{Hi}-\mathrm{Di}^{\mathrm{mm}}$ Formamide (Applied Biosystems) and $0.28 \mu \mathrm{l}$ of GeneScan ${ }^{\mathrm{Tm}}$ 120LIZ Size Standard (Applied Biosystems) were added to $6 \mu \mathrm{l}$ of primer extension products. All samples were loaded and run on an ABI Prism 310 DNA Genetic Analyzer (Applied Biosystems) following the manufacturer's recommendations. Following the run, samples were analyzed using GeneScan ${ }^{\mathrm{mm}} 3.1$ application software (Applied Biosystems).

\section{Results}

\section{Patients}

We used multiplex PCR plus primer extension method to detect EGFR -216 promoter region and exons 18-21 mutations in 81 cases of NSCLC (Figure 1). Histologically, there were 26 adenocarcinomas, 6 bronchioloaveolar carcinomas, 33 squamous cell carcinomas, 5 adenosquamous carcinomas, and 11 other types of NSCLCs.

\section{Multiplex PCR and primer extension}

For mutation analysis of codons 719 in exon 18, we used different-sized primers to recognize the change of the first and second base separately. In-frame deletion between codon 746 and 752 in codon 19 was analyzed with primers made to be different in size either by adding different lengths of poly $(\mathrm{dT})$ tails to the 5 '-end or extending the primer sequence to allow separation based on the 
Table 2: Primer extension mutation analysis probes for -216 promoter region and codons $719,746-750,790$, and 858 of the EGFR genes

\begin{tabular}{|c|c|c|c|}
\hline $\begin{array}{l}\text { Nucleotide number and } \\
\text { sequence }\end{array}$ & Amino acid change & Sequence & Size \\
\hline $2155 \mathrm{G}>\mathrm{T}, 2155 \mathrm{G}>\mathrm{A}$ & G719C, G719S & 5'-TGAATTCAAAAAGATCAAAGTGCTG-3' & 25 mer \\
\hline $2156 \mathrm{G}>\mathrm{C}$ & G719A & 5'-AAACTGAATTCAAAAAGATCAAAGTGCTGG-3' & 30 mer \\
\hline $2235-2249$ del & E746-A750 del & 5'-GAAGGTGAGAAAGTTAAAATTCCCGTCGCTATCAA-3' & 35 mer \\
\hline $2236-2250$ del & E746-A750 del & 5'-TCCCAGAAGGTGAGAAAGTTAAAATTCCCGTCGCTATCAAG-3' & $41 \mathrm{mer}$ \\
\hline 2237-2254 del & E746-T751 del & 5'-(T)20AGTTAAAATTCCCGTCGCTATCAAGG-3' & 46 mer \\
\hline $2240-2257$ del & L747-S752 del & 5'-(T)23AGTTAAAATTCCCGTCGCTATCAAGGAAT-3 & $52 \mathrm{mer}$ \\
\hline $2573 \mathrm{~T}>\mathrm{G}$ & L858R & 5'-(T)26ACCGCAGCATGTCAAGATCACAGATTTTGGGC-3' & 58 mer \\
\hline $2369 \mathrm{C}>\mathrm{T}$ & T790M & 5'-CTCCACCGTGCAGCTCATCA-3' & 20 mer \\
\hline$-216 \mathrm{G} / \mathrm{T}$ & & 5'-GGCCGCAGCAGCCTCC-3' & 16 mer \\
\hline
\end{tabular}

differences in size. SNP at -216 promoter region and missense mutations which result in L858R change in exon 21 and T790M in exon 20 were each analyzed with a single probe.

The overall mutation (in EGFR TK domain and -216 promoter) rate was $32 \%$ (26 of 81 ).

Mutations in exons 18-21 of EGFR TK domain were detected in 19 (23\%) of the 81 NSCLCs in which there were 12 adenocarcinomas, three bronchioloaveolar carcinomas, two squamous cell carcinomas, one adenosquamous carcinoma, and one other type of NSCLC. No mutation was detected at codon 719 in exon 18 and codon 790 in codon 20 . Seven tumors had in-frame deletions within exon 19, resulting in the loss of codons 746 through 750 in six tumors, and loss of codon 747 through 752 in one tumor. 12 cases had a $2573 \mathrm{~T}>\mathrm{G}$ mutation resulted in L858R change. SNP -216 in the promoter region were detected in seven $(8.6 \%)$ cases that include three adenocarcinomas, one bronchioloaveolar carcinoma, three squamous cell carcinomas. Three patients with SNP -216 in the promoter region had another mutation in exon 21 (L858R). Results of the multiplex PCR and primer extension mutation analysis of the EGFR gene are listed in Table 3.

\section{Direct Sequencing}

We also used direct sequencing to analyze the -216 promoter region and exons $18-21$ of the EGFR gene. The results of sequencing analysis were identical to the results of multiplex PCR with primer extension analysis. No other mutation was identified by direct sequencing. We can therefore conclude that our method was very accurate in profiling the most common EGFR mutations in NSCLC.

\section{Discussion}

EGFR proteins control essential signaling pathways that regulate cell proliferation [18]. Increased levels of EGFR gene expression are observed in many cancers, including NSCLC, and its expression is correlated with an adverse prognosis $[2-4,19]$. Clinical responsiveness to gefitinib and erlotinib in NSCLC have been shown to correlate with somatic mutations in the EGFR gene, which result in increased sensitivity to inhibition of growth by the drugs [8,10-12]. EGFR mutations have been found more frequently in non-smoking East Asian women with adenocarcinoma with bronchioalvelar features [14,20-26].

A protocol based on mutant-enriched PCR followed by primer extension of the PCR products was used to detect EGFR T790M mutation in NSCLC [27]. We recently demonstrated a simple and fast way to identify $K-R A S$ mutation [17]. In this study, we extend the application to detect -216 promoter region and exons 18-21 mutations of EGFR gene simultaneously and apply this method to investigate the mutation status in 81 cases of NSCLC. We compared the results with that from direct sequencing 


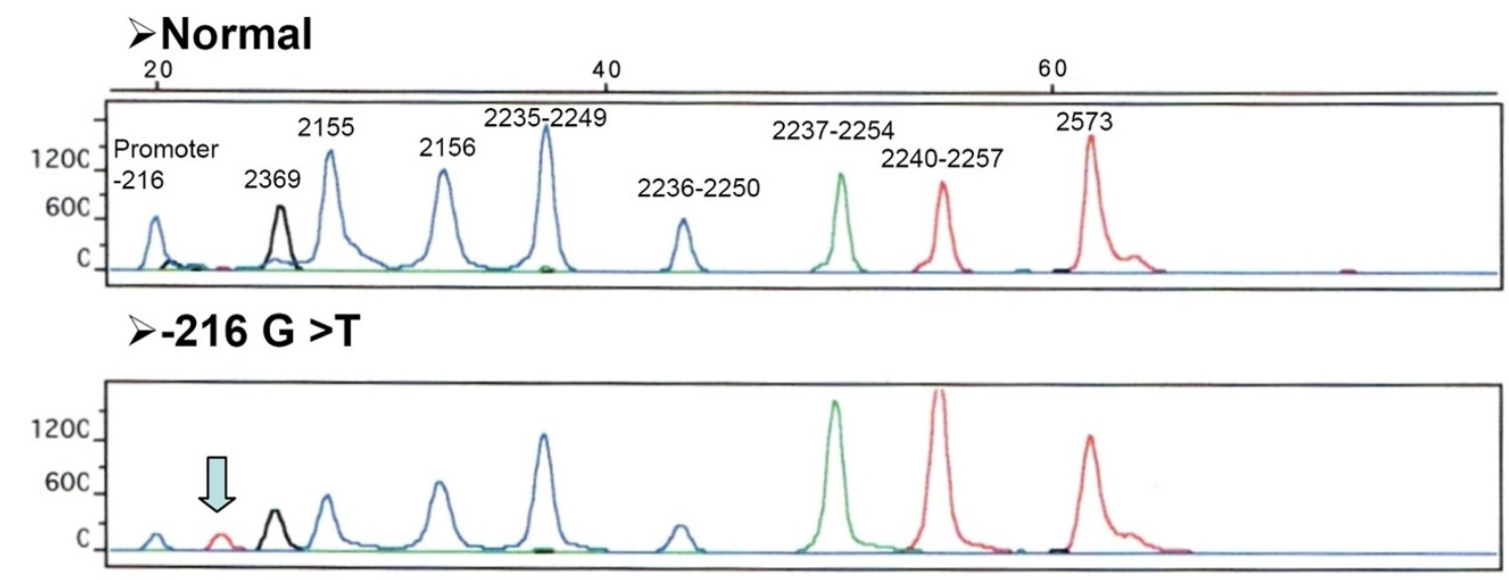

Del 2235-2249

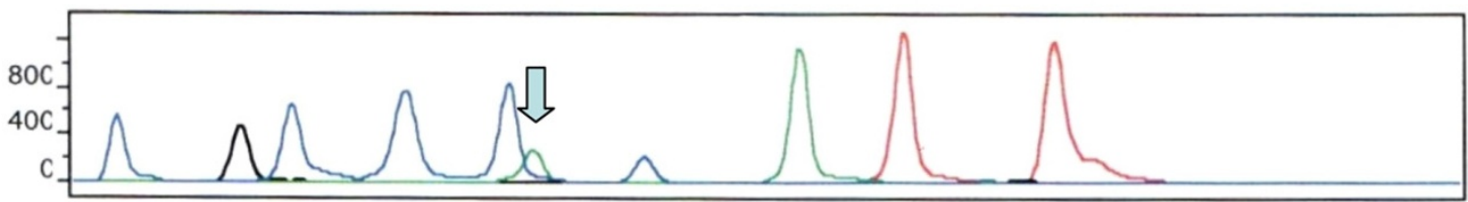

Del 2236-2250

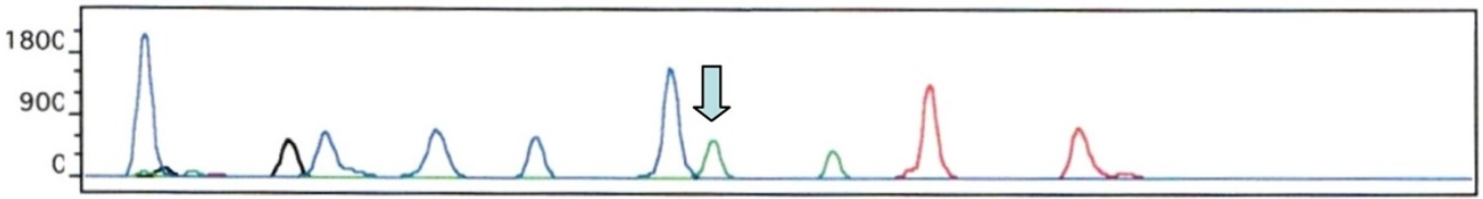

Del 2240-2257

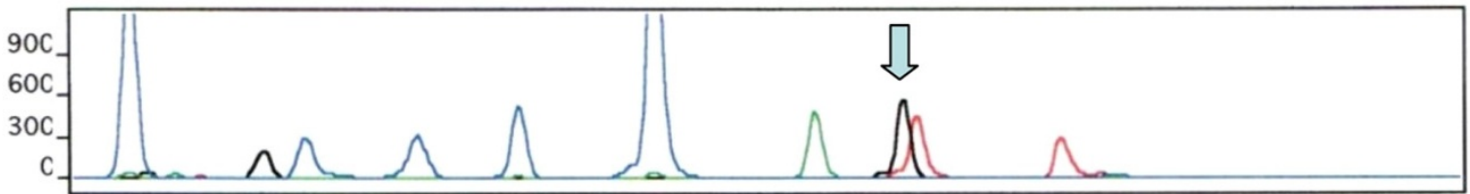

$2573 \mathrm{~T}>\mathrm{G}$

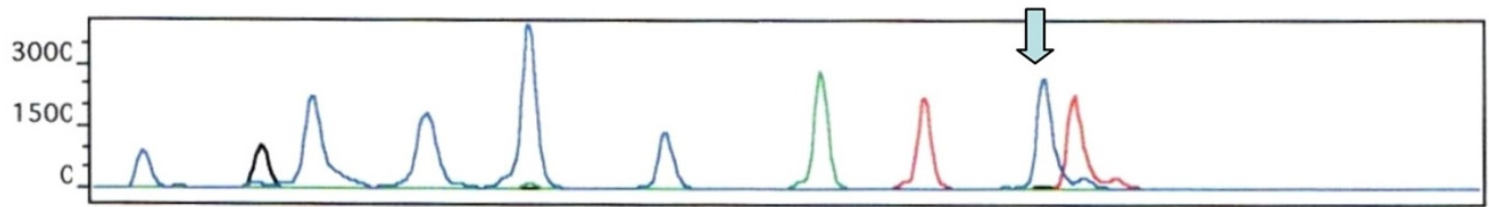

Figure 1 Detection of wild-type and mutant EGFR by primer extension analysis. NSCLC DNA samples of wild-type EGFR and ones containing the following mutations: -216 G/T, 2235-2249 del, 2236-2250 del, 2240-2257 del, and 2573 T>G.

for detecting EGFR mutations in 81 cases of NSCLC. The two protocols identified the same 26 mutations, but the new method is superior to direct sequencing in terms of the amount of work and time required. With this method, -216 promoter region and exons 18-21 of the EGFR gene were amplified with multiplex PCR in a single tube and the detection of mutations in the EGFR promoter and four key exons can be combined into one assay. This allows a sample to be screened for all common EGFR mutations simultaneously. We previously reported that 
Table 3: Mutation analysis of the EGFR gene by multiplex PCR and primer extension.

\begin{tabular}{|c|c|c|c|c|c|}
\hline \multirow{3}{*}{ NSCLC subtype } & \multicolumn{5}{|c|}{ Case(s) with EGFR mutation(s) } \\
\hline & \multirow[b]{2}{*}{$-216 \mathrm{G} / \mathrm{T}$} & \multicolumn{2}{|c|}{ E746-A750 del } & \multirow{2}{*}{$\begin{array}{l}\text { L747-S752 del } \\
2240-2257 \text { del }\end{array}$} & \multirow{2}{*}{$\begin{array}{r}L 858 R \\
2573 T>C\end{array}$} \\
\hline & & 2235-2249 del & $2236-2250 \mathrm{del}$ & & \\
\hline Adenocarcinoma $(\mathrm{n}=26)$ & 3 & 1 & 3 & 0 & 8 \\
\hline $\begin{array}{l}\text { Bronchioloalveolar } \\
\text { carcinoma }(\mathrm{n}=6)\end{array}$ & 1 & 2 & 0 & 0 & 1 \\
\hline $\begin{array}{l}\text { Squamous cell } \\
\text { carcinoma }(\mathrm{n}=33)\end{array}$ & 3 & 0 & 0 & 0 & 2 \\
\hline $\begin{array}{l}\text { Adenosquamous } \\
\text { carcinoma }(\mathrm{n}=5)\end{array}$ & 0 & 0 & 0 & 1 & 0 \\
\hline Others $(\mathrm{n}=11)$ & 0 & 0 & 0 & 0 & 1 \\
\hline Total $(\mathrm{n}=81)$ & 7 & 3 & 3 & 1 & 12 \\
\hline
\end{tabular}

that as little as $10 \mathrm{ng}$ of DNA was enough for the multiplex PCR reaction and we also showed that this method can detect mutations against a background of up to at least 23 wild-type alleles [3]. Moreover, because the technique is a sequencing-based approach, additional sequencing is not necessary.

Distinguishing sequence variants with primer extension is based on the high accuracy of nucleotide incorporation catalyzed by a DNA polymerase. Current products of the thermostable enzymes used in primer extension have very low error rates and are specific for ddNTPs [28]. These characteristics provide negligible primer misincorporation and excellent discrimination between wild, heterozygous and homozygous genotypes. Another advantage of the primer extension reaction is its multiplexing capability, with several mutations being detected in a single reaction tube. Multiplex PCR-SSCP- or PCRARMS-based methods can also simultaneously detect several mutations. However, PCR-SSCP require further confirmation by direct sequencing, and PCR-ARMS require more primers than are possible in a single reaction to detect all mutations at -216 promoter region and exons 18-21 of the EGFR gene. The primer extension reaction is a less time-consuming assay because automated fluorescent capillary electrophoresis of the products requires only 25 minutes in comparison with capillary electrophoresis required for standard sequencing that takes more than an hour.

\section{Conclusions}

The method that we demonstrated in this report provides a rapid way to identify common EGFR mutations for the purpose of clinical evaluation in NSCLC. The method can also be applied in the detection of other mutations in the EGFR gene.

\section{Competing interests}

The authors declare that they have no competing interests.

\section{Authors' contributions}

CHL performed PCR and primer extension and draft the manuscript, KTY participated in the design of the study, YSC performed direct sequencing, $\mathrm{NCH}$ participated in the analysis and helped to draft the manuscript, JGC designed the study.

\section{Acknowledgements}

This study was supported by Changhua Christian Hospital and Kaohsiung Medical University Hospital, Taiwan.

\section{Author Details}

1Department of Chest Medicine, Changhua Christian Hospital, Changhua, Taiwan, 2Department of Pathology, Changhua Christian Hospital, Changhua, Taiwan, ${ }^{3}$ Department of Laboratory Medicine, Kaohsiung Medical University Hospital, Kaohsiung, Taiwan, ${ }^{4}$ Department of Veterinary Medicine, National Chung Hsiung University, Taichung, Taiwan, 5 Institute of Clinical Medicine, Kaohsiung Medical University, Kaohsiung, Taiwan and ${ }^{6}$ Center for Excellence in Environmental Medicine, Kaohsiung Medical University, Kaohsiung, Taiwan

Received: 18 March 2010 Accepted: 12 May 2010

Published: 12 May 2010

\section{References}

1. Brambilla E, Travis WD, Colby TV, Corrin B, Shimosato Y: The new World Health Organization classification of lung tumours. Eur Respir J 2001, 18(6):1059-1068.

2. Hirsch FR, Varella-Garcia M, Bunn PA Jr, Di Maria MV, Veve R, Bremmes RM, Baron AE, Zeng C, Franklin WA: Epidermal growth factor receptor in nonsmall-cell lung carcinomas: correlation between gene copy number and protein expression and impact on prognosis. J Clin Oncol 2003, 21(20):3798-3807.

3. Nicholson RI, Gee JM, Harper ME: EGFR and cancer prognosis. Eur J Cancer 2001, 37(Suppl 4):S9-15.

4. Ohsaki Y, Tanno S, Fujita Y, Toyoshima E, Fujiuchi S, Nishigaki Y, Ishida S, Nagase A, Miyokawa N, Hirata S, Kikuchi K: Epidermal growth factor receptor expression correlates with poor prognosis in non-small cell lung cancer patients with p53 overexpression. Oncol Rep 2000, 7(3):603-607.

5. Veale D, Ashcroft T, Marsh C, Gibson GJ, Harris AL: Epidermal growth factor receptors in non-small cell lung cancer. Br J Cancer 1987, 55(5):513-516

6. Miller VA, Kris MG, Shah N, Patel J, Azzoli C, Gomez J, Krug LM, Pao W, Rizvi N, Pizzo B, Tyson L, Venkatraman E, Ben-Porat L, Memoli N, Zakowski M, 
Rusch V, Heelan RT: Bronchioloalveolar pathologic subtype and smoking history predict sensitivity to gefitinib in advanced non-smallcell lung cancer. J Clin Oncol 2004, 22(6):1103-1109.

7. Yang CH, Shih JY, Chen KC, Yu CJ, Yang TY, Lin CP, Su WP, Gow CH, Hsu C, Chang GC, Yang PC: Survival outcome and predictors of gefitinib antitumor activity in East Asian chemonaive patients with advanced nonsmall cell lung cancer. Cancer 2006, 107(8):1873-1882.

8. Byrne BJ, Garst J: Epidermal growth factor receptor inhibitors and their role in non-small-cell lung cancer. Curr Oncol Rep 2005, 7(4):241-247.

9. Sequist LV, Joshi VA, Janne PA, Bell DW, Fidias P, Lindeman NI, Louis DN, Lee JC, Mark EJ, Longtine J, Verlander P, Kucherlapati R, Meyerson M, Haber DA, Johnson BE, Lynch TJ: Epidermal growth factor receptor mutation testing in the care of lung cancer patients. Clin Cancer Res 2006, 12(14 Pt 2):4403s-4408s.

10. Pao W, Miller V, Zakowski M, Doherty J, Politi K, Sarkaria I, Singh B, Heelan R, Rusch V, Fulton L, Mardis E, Kupfer D, Wilson R, Kris M, Varmus H: EGF receptor gene mutations are common in lung cancers from "never smokers" and are associated with sensitivity of tumors to gefitinib and erlotinib. Proc Natl Acad Sci USA 2004, 101(36):13306-13311.

11. Paez JG, Janne PA, Lee JC, Tracy S, Greulich H, Gabriel S, Herman P, Kaye FJ, Lindeman N, Boggon TJ, Naoki K, Sasaki H, Fujii Y, Eck MJ, Sellers WR, Johnson BE, Meyerson M: EGFR mutations in lung cancer: correlation with clinical response to gefitinib therapy. Science 2004, 304(5676): 1497-1500.

12. Lynch TJ, Bell DW, Sordella R, Gurubhagavatula S, Okimoto RA, Brannigan BW, Harris PL, Haserlat SM, Supko JG, Haluska FG, Louis DN, Christiani DC, Settleman J, Haber DA: Activating mutations in the epidermal growth factor receptor underlying responsiveness of non-small-cell lung cancer to gefitinib. N Engl J Med 2004, 350(21):2129-2139.

13. Kobayashi S, Boggon TJ, Dayaram T, Janne PA, Kocher O, Meyerson M, Johnson BE, Eck MJ, Tenen DG, Halmos B: EGFR mutation and resistance of non-small-cell lung cancer to gefitinib. N Engl J Med 2005, 352(8):786-792

14. Kosaka T, Yatabe Y, Endoh H, Kuwano H, Takahashi T, Mitsudomi T: Mutations of the epidermal growth factor receptor gene in lung cancer: biological and clinical implications. Cancer Res 2004, 64(24):8919-8923.

15. Pao W, Miller VA, Politi KA, Riely GJ, Somwar R, Zakowski MF, Kris MG Varmus H: Acquired resistance of lung adenocarcinomas to gefitinib or erlotinib is associated with a second mutation in the EGFR kinase domain. PLoS Med 2005, 2(3):e73.

16. Liu W, Innocenti F, Wu MH, Desai AA, Dolan ME, Cook EH Jr, Ratain MJ: A functional common polymorphism in a Sp1 recognition site of the epidermal growth factor receptor gene promoter. Cancer Res 2005, 65(1):46-53.

17. Chang YS, Yeh KT, Chang TJ, Chai C, Lu HC, Hsu NC, Chang JG: Fast simultaneous detection of K-RAS mutations in colorectal cancer. BMC Cancer 2009, 9:179.

18. Oda K, Matsuoka Y, Funahashi A, Kitano H: A comprehensive pathway map of epidermal growth factor receptor signaling. Mol Syst Biol 2005 1:2005-0010

19. Krause DS, Van Etten RA: Tyrosine kinases as targets for cancer therapy. NEngl J Med 2005, 353(2):172-187.

20. Janne PA, Engelman JA, Johnson BE: Epidermal growth factor receptor mutations in non-small-cell lung cancer: implications for treatment and tumor biology. J Clin Oncol 2005, 23(14):3227-3234

21. Shigematsu H, Lin L, Takahashi T, Nomura M, Suzuki M, Wistuba II, Fong KM, Lee H, Toyooka S, Shimizu N, Fujisawa T, Feng Z, Roth JA, Herz J, Minna JD, Gazdar AF: Clinical and biological features associated with epidermal growth factor receptor gene mutations in lung cancers. $J$ Natl Cancer Inst 2005, 97(5):339-346.

22. Han SW, Kim TY, Hwang PG, Jeong S, Kim J, Choi IS, Oh DY, Kim JH, Kim DW, Chung DH, Im SA, Kim YT, Lee JS, Heo DS, Bang YJ, Kim NK: Predictive and prognostic impact of epidermal growth factor receptor mutation in non-small-cell lung cancer patients treated with gefitinib. $J$ Clin Oncol 2005, 23(11):2493-2501

23. Marchetti A, Martella C, Felicioni L, Barassi F, Salvatore S, Chella A, Camplese PP, larussi T, Mucilli F, Mezzetti A, Cuccurullo F, Sacco R, Buttitta F: EGFR mutations in non-small-cell lung cancer: analysis of a large series of cases and development of a rapid and sensitive method for diagnostic screening with potential implications on pharmacologic treatment. J Clin Oncol 2005, 23(4):857-865.
24. Mitsudomi T, Kosaka T, Endoh H, Horio Y, Hida T, Mori S, Hatooka S, Shinoda M, Takahashi T, Yatabe Y: Mutations of the epidermal growth factor receptor gene predict prolonged survival after gefitinib treatment in patients with non-small-cell lung cancer with postoperative recurrence. J Clin Oncol 2005, 23(11):2513-2520.

25. Tsao MS, Sakurada A, Cutz JC, Zhu CQ, Kamel-Reid S, Squire J, Lorimer I, Zhang T, Liu N, Daneshmand M, Marrano P, da Cunha Santos G, Lagarde A, Richardson F, Seymour L, Whitehead M, Ding K, Pater J, Shepherd FA: Erlotinib in lung cancer - molecular and clinical predictors of outcome. NEngl J Med 2005, 353(2):133-144.

26. Sharma SV, Bell DW, Settleman J, Haber DA: Epidermal growth factor receptor mutations in lung cancer. Nat Rev Cancer 2007, 7(3):169-181.

27. Inukai M, Toyooka S, Ito S, Asano H, Ichihara S, Soh J, Suehisa H, Ouchida M, Aoe K, Aoe M, Kiura K, Shimizu N, Date H: Presence of epidermal growth factor receptor gene T790M mutation as a minor clone in nonsmall cell lung cancer. Cancer Res 2006, 66(16):7854-7858.

28. Syvanen AC: From gels to chips: "minisequencing" primer extension for analysis of point mutations and single nucleotide polymorphisms. Hum Mutat 1999, 13(1):1-10.

doi: 10.1186/1423-0127-17-37

Cite this article as: Lin et al., Rapid detection of epidermal growth factor receptor mutations with multiplex PCR and primer extension in lung cancer Journal of Biomedical Science 2010, 17:37

\section{Submit your next manuscript to BioMed Centra and take full advantage of:}

- Convenient online submission

- Thorough peer review

- No space constraints or color figure charges

- Immediate publication on acceptance

- Inclusion in PubMed, CAS, Scopus and Google Scholar

- Research which is freely available for redistribution

Submit your manuscript at www.biomedcentral.com/submit
C) BioMed Central 